\title{
Anastrozole Promotes Implantation by Altering the Expression of Paxillin and FAK in Rat Luminal Uterine Epithelium
}

\author{
El Anastrozol Promueve la Implantación Alterando la Expresión \\ de Paxilina y FAK en el Epitelio Uterino Luminal de Rata
}

Anthony Mwakikunga'; Gbenga A Adefolaju²; Lynne Schepartz ${ }^{1}$ \& Margot J Hosie ${ }^{1,3}$

\begin{abstract}
MWAKIKUNGA, A.; ADEFOLAJU, G. A.; SCHEPARTZ, L. \& HOSIE, M. J. Anastrozole promotes implantation by altering the expression of paxillin and FAK in rat luminal uterine epithelium. Int. J. Morphol., 38(1):165-175, 2020.

SUMMARY: An alternative hyper-ovulator inducer to replace clomiphene citrate (CC) is needed as it is unsuitable for women with polycystic ovarian syndrome and is associated with low pregnancy rates. Anastrozole is an effective hyper-ovulator inducer, but has not been well researched. In order to determine the effectiveness of anastrozole as a hyper-ovulator inducer and to an extent compare it with CC in similar situations, this study ascertained the effects of these drugs on the expression of the focal adhesion proteins, paxillin and FAK, which are uterine receptivity markers in the surface luminal uterine epithelial cells of day 1 and day 6 pregnant Wistar rats. The results show that paxillin is localized in focal adhesions at the base of the uterine epithelial cells at day 1 of pregnancy whereas at day 6, paxillin disassembles from the basal focal adhesions and localizes and increases its expression apically. FAK is faintly expressed at the basal aspect of the uterine epithelial cells while moderately expressed at the cell-to-cell contact at day 1 in all groups from where it disassembles and relocates apically and becomes more intensely expressed at day 6 of pregnancy in untreated and anastrozole treated rats. Although paxillin is localized apically at day 6 , its expression is significantly down-regulated with CC treatment suggesting its interference with the implantation process. These findings seem to suggest that anastrozole could favor implantation.
\end{abstract}

KEY WORDS: Implantation; Uterus; Early pregnancy; Paxillin; FAK; Focal adhesion proteins.

\section{INTRODUCTION}

The cytoskeleton is an internal framework of a cell, and its reorganization is an ongoing process when cells adhere, move or invade extracellular substrates. In order for cells to adhere, they employ focal adhesions (FAs) (Lele et al., 2008; Fabry et al., 2011). The FAs are specialized structures formed where bundles of actin filaments are anchored to transmembrane integrins through a complex of adaptor and signaling proteins (Gilmore \& Burridge, 1996). FAs provide sites of mechanical attachment to the extracellular matrix (ECM) and are sites where adhesionassociated signal transductions are initiated (Fabry et al.). The binding of ligands to integrins on the extracellular side promotes recruitment of various intracellular proteins to the cytoplasmic tails of integrins that mechanically link them to the actin cytoskeleton (Hirata et al., 2014). Integrin signaling requires the non-receptor tyrosine kinase activities of the focal adhesion kinase (FAK) to initiate downstream signaling events (Lu \& Rounds, 2012). These signaling events culminate in reorganization of the actin cytoskeleton; a prerequisite for changes in cell shape and motility, gene expression and pregnancy (Lele et al.; Salgia, 2009; Fabry et al.; Kaneko et al., 2011).

Other studies have provided evidence to suggest that the structural links between actin filaments and integrins are regulated in at least some cell types, and it would not be unreasonable to hypothesize that agents known to alter cell behavior may do so by affecting the expression or function of actin binding proteins such as paxillin, and signaling molecules such as FAK which are recruited to focal adhesions (Kaneko et al., 2009; Mwakikunga et al., 2011). FAs are dynamically assembled and disassembled by cells including uterine luminal epithelial cells (Hosie et al., 2008; Kaneko et al., 2008, 2011) and these mechanisms are likely governed by the modulation of cross-talk between their constituent proteins, which influence their gene expression and morphology.

\footnotetext{
${ }^{1}$ School of Anatomical Sciences, University of the Witwatersrand Medical School, 7, York road, Parktown 2193, Johannesburg, South Africa.

${ }^{2}$ Department of Pre-Clinical Sciences, School of Health Care Sciences, University of Limpopo. Private Bag x1106, Sovenga 0727, South Africa.

${ }^{3}$ Newcastle University Medicine Malaysia Campus, Nusajaya, Johor, Malaysia.

Funding this work was funded by grants from the National Research Foundation and Medical Research Council of South Africa, the government of Norway (NORAD project) and College of Medicine, University of Malawi.
} 
The assembly, disassembly and reorganization of FA proteins during early pregnancy are part of the process of plasma membrane transformation (Kaneko et al., 2011). During implantation, FA proteins disassemble from the base of the epithelium to facilitate the detachment of the uterine luminal epithelium to allow the embryo to invade the endometrium. At the same time, they assemble and become localized apically to assist in the adhesion of the blastocyst onto the endometrium (Kaneko et al., 2011, 2012).

Aromatase inhibitors were originally developed for the treatment of advanced breast cancer in postmenopausal women (Dukes et al., 1996). Anastrozole is a selective and highly potent aromatase inhibitor (Mitwally \& Casper, 2001). Aromatase inhibitors can induce ovulation by preventing feedback by estrogen on the gonadotropin releasing hormone and gonadotropin secretion, leading to an increase in follicle stimulating hormone (FSH) and luteinizing hormone ( $\mathrm{LH})$ production, which stimulates ovarian follicular development and ovulation (Mitwally \& Casper, 2002). Aromatase inhibitors may act on critical amino acid residues in the aromatase active site and access channel to interfere with the enzyme activity and haem stability thus preventing the aromatization of androgens to estrogens (Lo et al., 2013).

Anastrozole is clinically effective in ovulation induction (Karaer et al., 2005; Badawy et al., 2008), but it has not been well researched (Tredway \& Schertz, 2011). Chlomiphene citrate (CC) is the first-line and most commonly used oral agent for the induction of ovulation (Casper \& Mitwally, 2011), but it is associated with low pregnancy rates (Nutu et al., 2010; Racette et al., 2010). Understanding the effects of anastrozole on implantation in vivo enables manipulation of uterine receptivity to control fertility and to improve the outcome of assisted reproductive procedures (Karaer et al.).

The aim of this study was to determine the effects of anastrozole on the gene and protein expression levels and localization of focal adhesion proteins, paxillin and FAK, in the rat uterine epithelial cells during implantation in vivo.

\section{MATERIAL AND METHOD}

Animals. The study was approved by the University of the Witwatersrand Animal Ethics Committee.

Forty female virgin Wistar rats were divided into 8 treatment groups of five: $15 \mathrm{mg} / \mathrm{kg}$ anastrozole, $1.25 \mathrm{mg} / \mathrm{kg}$ chlomiphene citrate (CC), carrier and untreated of day 1 and day 6 of pregnancy. Rats were housed in plastic cages at 21 ${ }^{\circ} \mathrm{C}$ under a controlled 12 hour light-dark cycle. They were provided with water and food ad libitum (Dukes et al.). Vaginal smears were obtained from all female rats to confirm that they had regular cycles for two cycles before drug administration (Singletary et al., 2005; Jaramillo et al., 2012). Vaginal smear was done in the late afternoon (Kaneko et $a l ., 2008$ ) and rats in pro-oestrus were treated with the drugs or placebo then caged overnight with males of proven fertility. The morning of finding the vaginal plug or presence of spermatozoa in the smear was designated as day 1 of pregnancy (Kaneko et al. 2008). Table I shows treatment regimes for the rats undergoing ovulation stimulation.

Table I. Treatment regimes for the 8 groups of mature female Wistar rats undergoing ovulation stimulation.

\begin{tabular}{lll}
\hline Groups & Treatments & Number of rats \\
\hline 1 & Day 1 untreate d & 5 \\
2 & Day 1 saline (carrier) & 5 \\
3 & Day 1 anastroz ole & 5 \\
4 & Day 1 CC & 5 \\
5 & Day 6 untreate d & 5 \\
6 & Day 6 saline (carrier) & 5 \\
7 & Day 6 anastroz ole & 5 \\
8 & Day 6 CC & 5 \\
\hline
\end{tabular}

Treatment regimens: Groups 1 and 5 were left untreated (negative control). Groups 2 and 6 (carrier control groups) received the vehicle sterile saline. Groups 3 and 7 received a single dose of $15 \mathrm{mg} / \mathrm{kg}$ of body weight anastrozole in the proestrous phase intraperitoneally. Groups 4 and 8 received $1.25 \mathrm{mg} / \mathrm{kg}$ of body weight $\mathrm{CC} ; \mathrm{n}=5$ in each group, all 0.2 $\mathrm{ml}$ intraperitoneal injections.

Rationale for the doses: A daily dose of $1 \mathrm{mg} / \mathrm{kg}$ anastrozole for 5 days is the standard recommended dose in humans (Al-Omari et al., 2004). A 12-14 week mature female Wistar rat weighs between 200-250g with a 4-day estrous cycle so a single dose of anastrozole administered at pro-estrus was deemed appropriate. Kilic-Okman et al. (2003) employed a similar regime using Letrozole. Earlier studies have suggested that the standard $1 \mathrm{mg} / \mathrm{kg}$ anastrozole of body weight dose is too low for optimal follicle recruitment and ovulation, so higher doses are recommended (Al-Omari et al.; Casper \& Mitwally). The single $25 \mathrm{mg} / \mathrm{kg}$ anastrozole dose has been successful in inducing ovulation in mice and is associated with favorable embryo development (Karaer et al.). However, in our preliminary work, a drug concentration study with anastrozole was carried out to determine the optimal dose to be used to superovulate and achieve pregnancy in the Wistar rats (Mwakikunga \& Hosie, 2016). This was found to be dose-specific, and the $15 \mathrm{mg} /$ 
$\mathrm{kg}$ anastrozole dose superovulated and achieved pregnancy the most; therefore, this dose was used in the subsequent experiments in this study. The CC dose was adopted from earlier studies (Hosie et al., 2003) and used as a comparison.

Drug preparation and administration: The vehicle for all of the drugs was normal saline and each injection consisted of $0.2 \mathrm{ml}$ normal saline including the drug per injection per rat. All injections were intraperitoneal. The $15 \mathrm{mg} / \mathrm{kg}$ body weight anastrozole dose was found to be the optimal dose for the preliminary dose response study whereas the 1.25 $\mathrm{mg} / \mathrm{kg}$ of body weight, CC was used which was adopted from previous studies (Hosie et al., 2003).

Tissue preparation: Pregnant rats were sacrificed on day 6 at the time of implantation using a lethal dose $(0.35 \mathrm{ml})$ of Euthanase, intraperitoneally ( $1 \mathrm{ml} / \mathrm{kg}$ is recommended; Kyron Labs, South Africa). Once deeply unconscious, the abdominal cavity was opened and all rats to be sacrificed on day 6 of pregnancy were injected intravenously using the inferior vena cava with $0.1 \mathrm{ml}$ of $1 \%$ high molecular weight vital dye Pontamine sky blue (Sigma, St. Louis, MO, USA) in normal saline $(0.9 \% \mathrm{NaCl})$ (Pakrasi \& Tiwari, 2007), in order to distinguish implantation sites from non-implantation sites. This dye quickly localizes in the implantation sites due to increased vascularization and vascular permeability during early pregnancy (Psychoyos et al., 1995). After removal of the uterine horns, implantation sites were counted and recorded. The uterus was cut into $1 \mathrm{~cm}$ pieces separating implantation and non-implantation sites for immunofluorescence and confocal microscopy and real-time quantitative polymerase chain reaction (qPCR).

Tissue processing and sectioning: Using standard procedures, samples for immunofluorescence and confocal microscopy were fixed in $10 \%$ buffered formalin for 48 hours (Karaer et al.), then placed in an automatic tissue processor (Shandon Citadel 1000, Labotek, South Africa) in which samples were incubated in a series of $70 \%, 95 \%$, $95 \%, 95 \%, 100 \%, 100 \%, 100 \%$ ethanol then in chloroform and finally in paraffin wax. Samples were then embedded in paraffin wax. Histological sections $(5 \mu \mathrm{m})$ were cut using a Leica 2035 Biocut microtome (Leica, Nussloch, Germany) fitted with a disposable blade and then dewaxed overnight by placing them in an oven at $60{ }^{\circ} \mathrm{C}$, then immersed in histoclear for 5 minutes and then repeated in fresh histoclear for 5 minutes, rehydrated through a graded series of ethanol $(100 \%, 100 \%, 95 \%, 80 \%, 70 \%$ and $60 \%)$ for 30 seconds each, then washed in running water for 5 minutes (Faoláin et al., 2005; Karaer et al.).

Immunofluorescence and confocal microscopy: The immunolocalization and double labeling protocol was adopted and modified from previous studies (Mohan et al., 2008; Kaneko et al., 2011; Mwakikunga et al.). De-waxed sections of uterus from each group were washed 3 times, 2 min each with PBS. This was followed by a $10 \mathrm{~min}$ incubation in $30 \% \mathrm{H}_{2} \mathrm{O}_{2}$ (Sigma-Aldrich Co., St. Louis, MO, USA) in methanol to block endogenous peroxidase activity (Mwakikunga et al.), and then washed 3 times, 2 min each with PBS. Sections were then permeabilized for 30 minutes in $0.1 \%$ Triton-X 100 (Sigma-Aldrich Co., St. Louis, MO, USA) in PBS, and incubated for 30 minutes in blocking solution $(5 \%(\mathrm{v} / \mathrm{v})$ normal goat serum (SigmaAldrich Co., St. Louis, MO, USA) in PBS. All primary and secondary antibodies were diluted in blocking solution (1:100) (Mwakikunga et al.). Sections were incubated with primary antibodies rabbit monoclonal anti-FAK and mouse monoclonal anti-Paxillin (Abcam, Cambridge, MA, USA) for 24 hours at $4{ }^{\circ} \mathrm{C}$ (double staining) (Mohan et al.). After washing with PBS 3 times 5 min each, sections were incubated with fluorescein isothiocyanate (FITC) conjugated AffiniPure Goat anti-mouse IgG secondary antibody (Abcam) and rodamine conjugated Goat anti-rabbit IgG secondary (Abcam) at a dilution of 1:100 (Mwakikunga et al.) for $30 \mathrm{~min}$ in the dark followed by 3 PBS washes of 5 min each. Sections were also counterstained with DAPI to label nuclei. Expression and localization of Paxillin and FAK were examined under the Zeiss LSM 780 confocal microscope (Carl Zeiss, Jena, Germany) and images were acquired using the Zeiss LSM software (Carl Zeiss, Jena, Germany). The focal adhesion protein expression levels and localization in the confocal images were scored using a scoring method modified from previous studies (Englund et al., 2001) as shown in Table II. A JMP10 software (SAS Institute, Cary, NC, USA) was used for the statistical comparisons of means of focal adhesion protein expression of paxillin and FAK among treatment groups using a oneway ANOVA followed by a Tukey-Kramer post hoc analysis. Differences were considered statistically significant when $\mathrm{p}<0.05$.

Real time quantitative polymerase chain reaction (qPCR): In this study, the qPCR was performed for the quantitation of gene expression of the focal adhesion proteins paxillin and FAK in the uterine epithelial cells from day 1 and day 6 pregnant rats of all treatment regimes. The house keeping genes, $\beta$-actin, $18 \mathrm{Sr}$ RNA and Lactate dehydrogenase A (Ldha) were used as reference genes (AlBader \& Al-Sarraf, 2005; Hong et al., 2006; Li et al., 2013). The RNA from the uterine epithelial cells was prepared with the GeneJET RNA purification kit (Thermo Scientific Inc., 2011), and genomic DNA was removed according to the manufacturer's instructions (Thermo Scientific Inc., 2011). For qPCR, amplification was performed in a 7500 real-time PCR cycler (Applied Biosystems, Foster City, CA) and 
Table II. A description of the scoring system for the focal adhesion protein expression and localization in the confocal images among treatment groups adopted from previous studies (Englund et al., 2001; Mwakikunga et al., 2011).

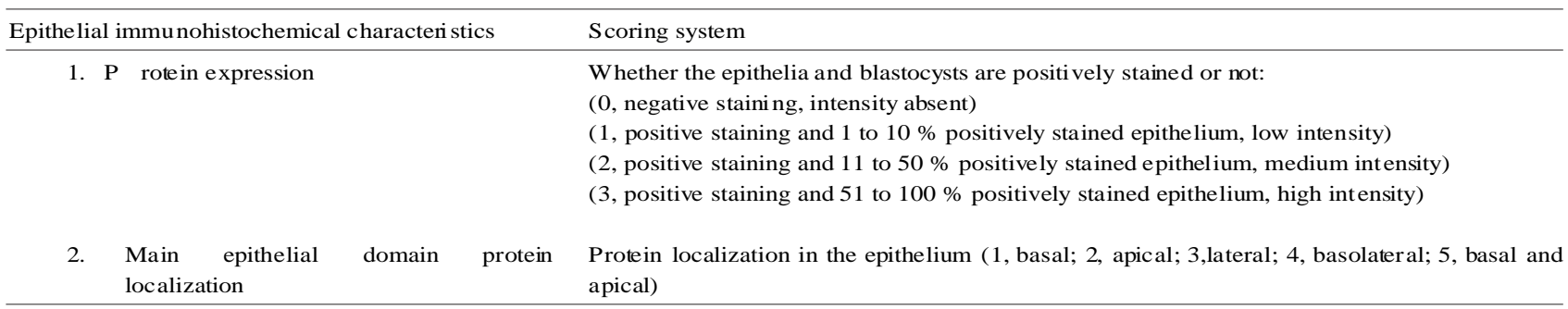

revealed with a QuantiFast SYBR Green PCR kit (Thermo Fisher Scientific Inc., 2011). The amplification cycling conditions were as follows: $95^{\circ} \mathrm{C}$ for $10 \mathrm{~min},\left(95^{\circ} \mathrm{C}\right.$ for 15 $\mathrm{s}, 60^{\circ} \mathrm{C}$ for $1 \mathrm{~min}$ in 40 cycles), $95^{\circ} \mathrm{C}$ for $15 \mathrm{~s}, 60^{\circ} \mathrm{C}$ for 1 min, $95^{\circ} \mathrm{C}$ for $30 \mathrm{~s}, 60^{\circ} \mathrm{C}$ for $15 \mathrm{~s}$. Table III shows the primer sequences for the real-time qPCR.

SYBR green qPCR data analysis: The $2-\Delta \Delta C T$ method was used to determine the gene expression fold change relative to the control (calibrator sample) following drug treatment regimes (Schmittgen \& Livak, 2008). The data (threshold cycle or ct values) were first normalized using the three reference genes $\beta$-actin, 18S rRNA and lactate dehydrogenase A; then the fold change was calculated (Schmittgen \& Livak). The JMP10 software was used to conduct statistical analyses on the data. A one-way ANOVA followed by a Tukey-Kramer post hoc analysis was performed to compare the means of normalized relative quantities (NRQ) between treatment groups. Differences were considered statistically significant when $p<0.05$.

\section{RESULTS}

Paxillin and FAK: Paxillin is localized in focal adhesions at the base of the uterine epithelial cells at day 1 of pregnancy whereas at day 6 , paxillin disassembles from the basal focal adhesions and localizes and increases its expression apically as shown in Figures 1, 2 and 3. FAK is faintly expressed at the basal aspect of the uterine epithelial cells while moderately expressed at the cell-to-cell contact at day 1 in all groups from where it disassembles and relocates apically and becomes more intensely expressed at day 6 of pregnancy in untreated and anastrozole treated rats (Figs. 1-3). Although paxillin is localized apically at day 6 , its expression is significantly down-regulated with CC treatment suggesting its interference with the implantation process. However, there is a significant difference $(\mathrm{p} \leq 0.0001)$ in the expression levels of paxillin and FAK between untreated (control) and CC treated rats, anastrozole and $\mathrm{CC}$ treated rats at day 6 suggesting that $\mathrm{CC}$ appears to decrease their expression.

Table III. Description of the real time PCR primer sequence characteristics for the genes of interest and reference genes used in the study.

\begin{tabular}{|c|c|c|c|c|c|c|}
\hline $\begin{array}{l}\text { Gene } \\
\text { symbol }\end{array}$ & Gene name & $\begin{array}{l}\text { RefSeq } \\
\text { GenBank } \\
\text { Accession }\end{array}$ & $5^{\prime}-3^{\prime}$ primer sequence & $\begin{array}{ll}\text { Position } & \text { of } \\
\text { primer } & \text { on } \\
\text { template } & \end{array}$ & GC content & $\begin{array}{l}\text { Amplicon } \\
\text { length (bp) }\end{array}$ \\
\hline Pxn & Paxillin & NM 001012147 & $\begin{array}{l}\text { F: 5'- AGT GTT CTT GTC AGA GGA GCC } \\
\text {-3' (21 bases) } \\
\text { R: 5'- GCT GCC ATT GGT CTA AGG GG - } \\
\text { 3' (20 bases) }\end{array}$ & $\begin{array}{l}171--190 \\
282--263\end{array}$ & $\begin{array}{l}52.3 \% \\
60 \%\end{array}$ & 112 \\
\hline Ptk2 & $\begin{array}{l}\text { Protein tyrosine } \\
\text { kinase } 2 \text { (fo cal } \\
\text { adhesion kinase) }\end{array}$ & NM 013081.2 & $\begin{array}{l}\text { F: 5'- ATC AAG GCG TGT ACC TGA GC - } \\
\text { 3' (20 bases) } \\
\text { R: 5'- GGT CAA ACT GGC GCA TTG TT - } \\
\text { 3' (20 bases) }\end{array}$ & $\begin{array}{l}2360--2379 \\
2445--2426\end{array}$ & $\begin{array}{l}55 \% \\
50 \%\end{array}$ & 86 \\
\hline Actb & Actin, beta & NM 031144.3 & $\begin{array}{l}\text { F: 5' - GCA GGA GTA CGA TGA GTC CG } \\
-3^{\prime}(20 \text { bases) } \\
\text { R: 5' - ACG CAG CTC AGT AAC AGT CC } \\
\left.-3^{\prime} \text { ( } 20 \text { bases }\right)\end{array}$ & $\begin{array}{r}1155--1174 \\
1228--1209\end{array}$ & $\begin{array}{l}60 \% \\
55 \%\end{array}$ & 74 \\
\hline Ldha & $\begin{array}{l}\text { Lactate } \\
\text { dehydrogenase A }\end{array}$ & NM 017025.1 & $\begin{array}{l}\text { F: 5' - CCG TTA CCT GAT GGG AGA AA } \\
-3^{\prime}(20 \text { bases) } \\
\text { R: 5' - ACG TTC ACA CCA CTC CAC AC } \\
\left.-3^{\prime} \text { ( } 20 \text { bases }\right)\end{array}$ & $\begin{array}{l}613--632 \\
720--701\end{array}$ & $50 \%$ & 108 \\
\hline $18 \mathrm{~s}$ & 18S r RNA & X01117.1 & $\begin{array}{l}\text { F: 5' - GTT GGT TTT C GG AAC TGA } \\
\text { GGC -3' (21 bases) } \\
\text { R: 5' - GTC GGC ATC GTT TAT GGT CG } \\
\left.-3^{\prime} \text { ( } 20 \text { bases }\right)\end{array}$ & $\begin{array}{l}895--915 \\
1098--1079\end{array}$ & $52.4 \%$ & 204 \\
\hline
\end{tabular}



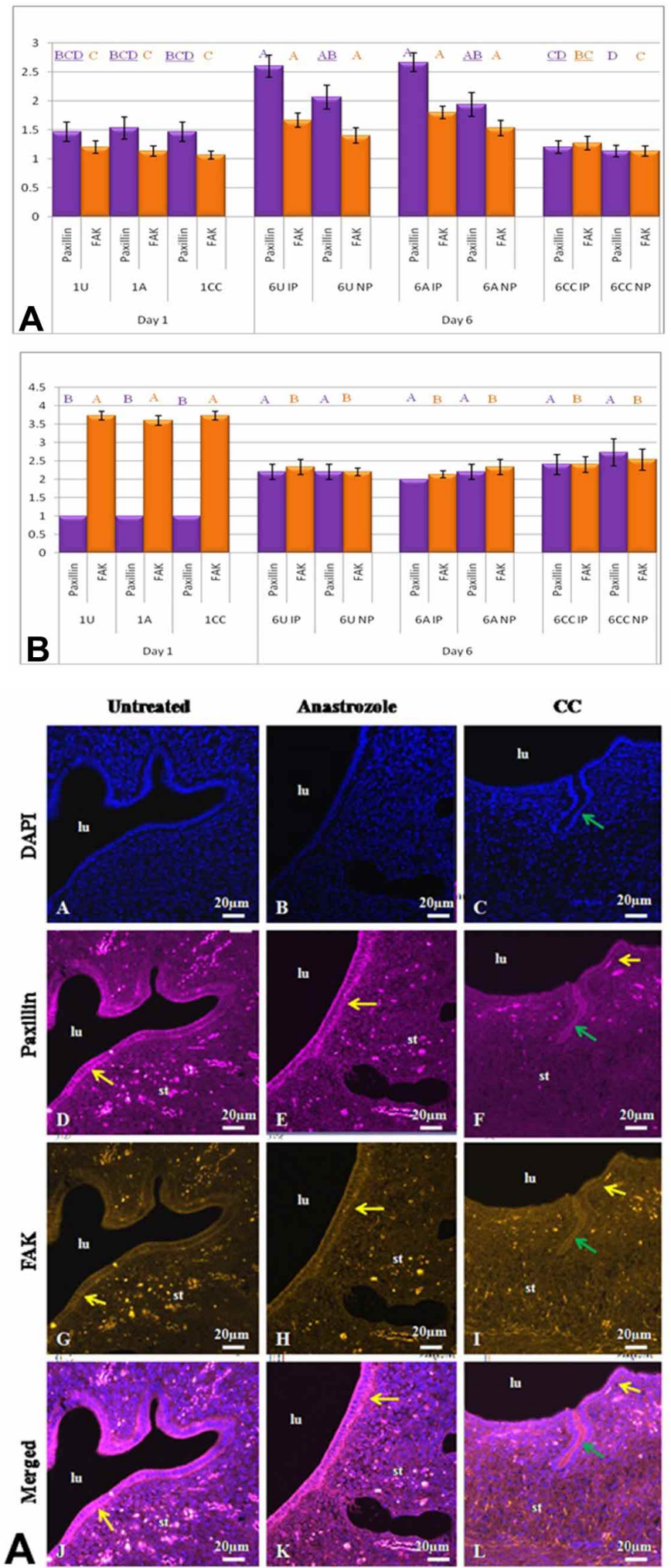

Fig. 1. (A) Graphical representation of paxillin and FAK expression in luminal uterine epithelial cells in pregnant rats. There is a significant difference in the expression levels of paxillin and FAK between untreated (control) and $\mathrm{CC}$ treated rats, anastrozole and $\mathrm{CC}$ treated rats at day $6(\mathrm{p} \leq 0.001)$ suggesting that $\mathrm{CC}$ appears to decrease their expression. No significant difference is noted between untreated and anastrozole treated rats at day 6 ( $p \geq 0.05$ ), although the means for paxillin and FAK expression are higher in the anastrozole treated than in the untreated groups. (B) Graphical representation of paxillin and FAK localization in the uterine epithelial cells in pregnant rats. Paxillin is localized in focal adhesions at the base of the uterine epithelial cells at day 1 of pregnancy whereas at day 6 , paxillin disassembles from the basal focal adhesions and localizes apically. FAK is faintly expressed at the basal aspect of the uterine epithelial cells while moderately expressed at the cellto-cell contact (lateral aspect) of the uterine epithelial cells at day 1 in all groups from where it disassembles and relocates apically and becomes more intensely expressed at day 6 of pregnancy in untreated and anastrozole treated rats.
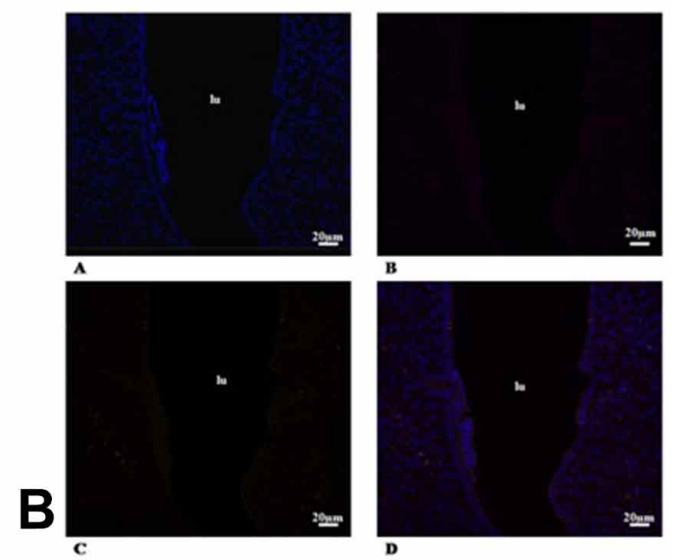

Fig. 2. (A) Micrograph showing paxillin and FAK expression and localization in luminal uterine epithelial cells from day 1 of pregnancy in rats. (A), (B) and (C) show nuclei stained with DAPI (blue). (D) and (E) A distinct band of paxillin (magenta, FITC) expression at the base of the uterine epithelium (yellow arrow) is noted in both untreated and anastrozole treated rats. (F) The basal expression of paxillin in CC treated rat is not as high as in (D) and (E). (G), (H) and (I) Very faint band of FAK (orange, rodamine) expression is noted at the base of the uterine epithelium (yellow arrow) in untreated, anastrozole treated and $\mathrm{CC}$ treated rats. FAK expression of medium intensity is also noted on the lateral domain of the epithelium. $(\mathrm{K})$ and $(\mathrm{L})$ Paxillin and FAK do not co-localize basally on day 1 of pregnancy. All images are representative of staining from the 5 rats in each of the treatment regimes. (B) Non-immune control micrograph (A) Shows nuclei stained with DAPI (blue). (B) Non staining of secondary antibody for anti-Paxillin. (C) Non staining of secondary antibody for anti-FAK. (D) Merged micrograph of (A), (B) and (C). 
Although there is no significant difference $(\mathrm{p} \geq 0.05)$ between untreated and anastrozole treated rats at day 6 , the means for paxillin and FAK expression are higher in the anastrozole treated than in the untreated groups. Paxillin and FAK do not co-localize in focal adhesions at the base of the epithelium at day 1, but they co-localize and increase their expression apically at day 6 suggesting their role in the implantation process. The non-immune controls (Fig. 2b) were used to

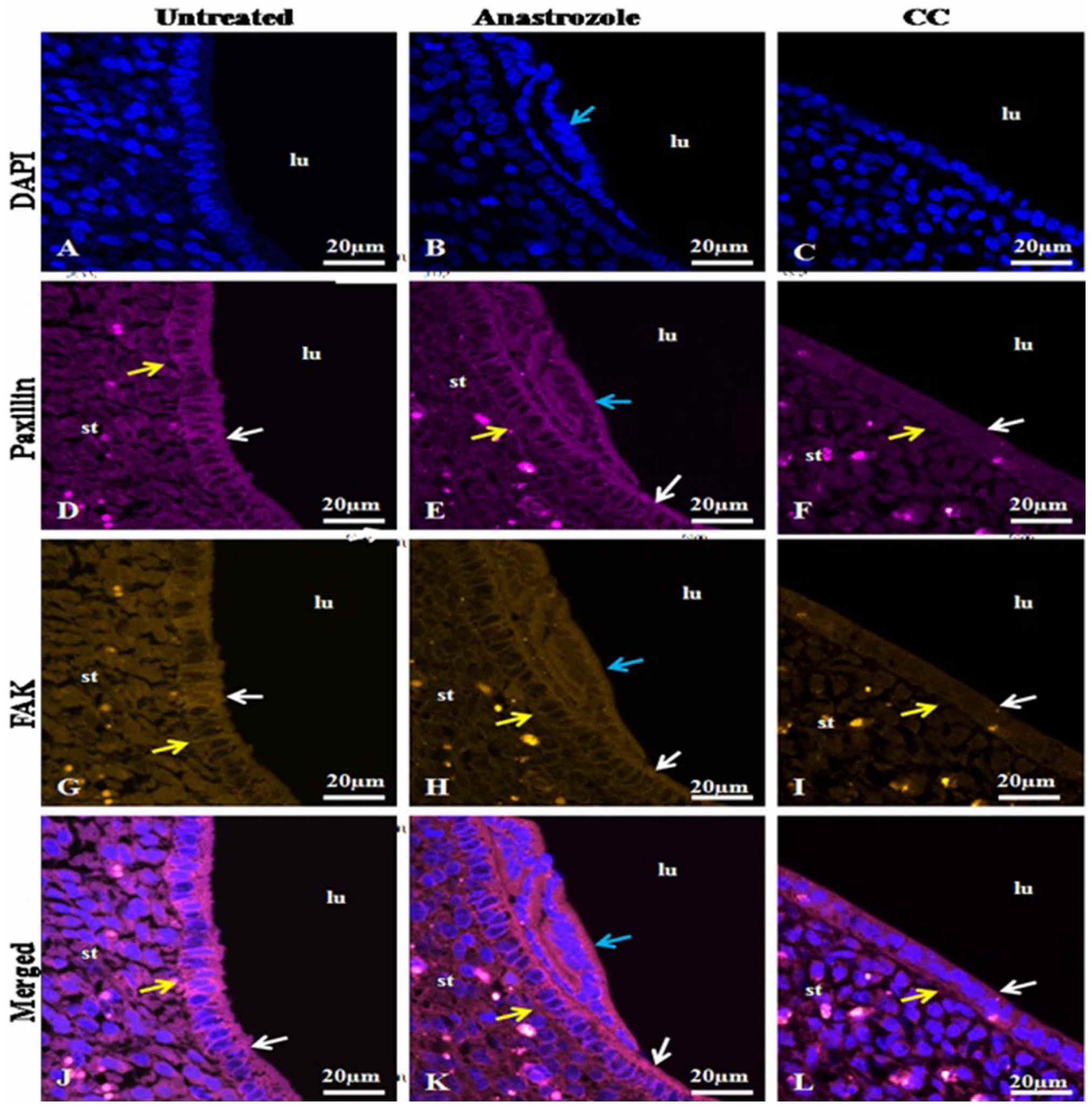

Fig. 3. Micrograph showing paxillin and FAK expression and co-localization in luminal uterine epithelial cells from implantation sites of day 6 pregnant rats. (A), (B) and (C) show nuclei stained with DAPI (blue); orange arrow shows the embryo. (D) and (E) paxillin (Magenta, fluorescein isothiocyanate (FITC) disassemble from the base of the epithelium (yellow arrows) and become significantly highly expressed apically ( $\mathrm{p} \leq 0.001$ ) (white arrows) in both untreated and anastrozole treated rats. (F) The apical expression of paxillin in $\mathrm{CC}$ treated rat is down-regulated. $(\mathrm{G})$ and (H) FAK (orange, rodamine) become highly expressed apically (white arrows) in both untreated and anastrozole treated rats. (I) The apical expression of FAK in CC treated rat is significantly unchanged (p $\geq 0.05)$. (J), (K) and (L) Paxillin and FAK co-localize apically on day 6 of pregnancy. All images are representative of staining from the 5 rats in each of the treatment regimes. 
validate and determine non-specific binding of the secondary antibody on other targets within the epithelium; there is no non-specific binding.

Relative quantification (RQ) analysis of paxillin and FAK gene expression in the uterine epithelial cells from day 1 and day 6 pregnant rats: At day 1 of pregnancy, paxillin gene expression is fairly similar (1.02-fold increase) in the anastrozole treated rats relative to the calibrator sample (day 1 untreated rats). This is also true for FAK gene expression (1.02-fold increase). Paxillin gene expression is slightly down-regulated (0.59-fold decrease) in the $\mathrm{CC}$ treated group when compared to the calibrator sample. This is also true for FAK gene expression (0.64-fold decrease) as shown in Tables IV, V and Figure 4. Notably, at day 6 of pregnancy, paxillin and FAK gene expression are significantly up-

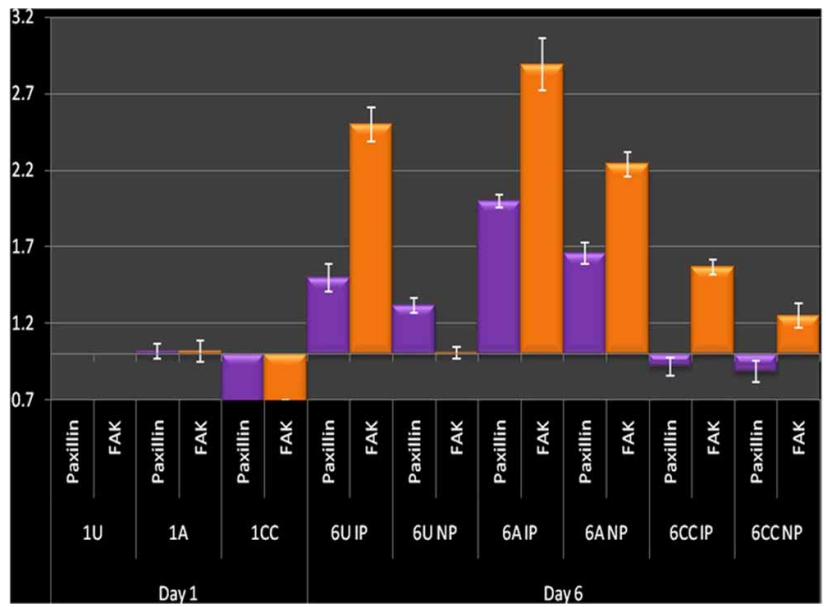

Fig. 4. Graphical representation of paxillin and FAK gene expression in luminal uterine epithelial cells in pregnant rats. There is a significant difference in the gene expression levels of paxillin and FAK between untreated (control) and CC treated rats, anastrozole and $\mathrm{CC}$ treated rats at day $6(\mathrm{p} \leq 0.001)$ suggesting that CC appears to decrease their expression. No significant difference is noted between untIn this study, paxillin is localized in focal adhesions at the base of regulated (more than 1.5 -fold increase) $(\mathrm{p} \leq 0.0001)$ in the implantation and non-implantation sites in the anastrozole treated group relative to the calibrator sample (Tables IV, V and Fig. 4). A significant increase in the paxillin gene expression is also noted in the day 6 implantation sites in the untreated group (more than 1.5-fold increase) $(\mathrm{p} \leq 0.0001)$ while it has remained similar (1.32-fold increase) in the nonimplantation sites relative to the calibrator sample (Fig. 4). On the other hand, paxillin is down-regulated with $\mathrm{CC}$ treatment at day 6 in implantation sites (0.92-fold decrease) and non-implantation sites ( 0.89 -fold decrease) relative to the calibrator sample. Interestingly, $\mathrm{CC}$ seems not to downregulate FAK gene expression in implantation and nonimplantation sites at day 6 (1.57-fold increase and 1.25-fold increase respectively) when compared to the calibrator sample as shown in Table V and Figure 4. In general, there is an increase in paxillin and FAK gene expression as pregnancy progresses, asreflected in the immunofluorescence experiments.

\section{DISCUSSION AND CONCLUSIONS}

In this study, paxillin is localized in focal adhesions at the base of the uterine epithelial cells at day 1 of pregnancy whereas at day 6 , paxillin disassembles from the basal focal adhesions and localizes and increases its expression apically. Additionally, FAK is faintly expressed at the basal aspect of the uterine epithelial cells while moderately expressed at the cell-to-cell contact at day 1 in all groups from where it disassembles and relocates apically and becomes more intensely expressed at day 6 of pregnancy in untreated and anastrozole treated rats. Although paxillin is localized apically at day 6 , its expression is significantly downregulated with $C C$ treatment $(p \leq 0.0001)$ suggesting its interference with the implantation process. However, there is a significant difference in the expression levels of paxillin

Table IV. RQ analysis of paxillin gene expression in the luminal surface uterine epithelial cells of day 1 and day 6 of pregnant rats. A fold change of 1.5 or more represents a significant difference in gene expression.

\begin{tabular}{lllllll}
\hline Sample & Pax Ave $\mathrm{C}_{\mathrm{T}}$ & $*$ RFG Ave $\mathrm{C}_{\mathrm{T}}$ & $\Delta \mathrm{C}_{\mathrm{T}}$ & $\Delta \Delta \mathrm{C}_{\mathrm{T}}$ & $\begin{array}{l}\log _{10} \\
\left(2^{-\Delta \Delta C \mathrm{CT}}\right)\end{array}$ & $\begin{array}{l}\text { Fold change } \\
2^{-\Delta \Delta C \mathrm{CT}}\end{array}$ \\
\hline$* * 1 \mathrm{U}$ & $22.82 \pm 0.03$ & $22.81 \pm 0.03$ & $0.01 \pm 0.04$ & $0 \pm 0.04$ & 0 & $1(0.97$ to 1.03$)$ \\
1 A & $22.74 \pm 0.03$ & $22.75 \pm 0.04$ & $-0.01 \pm 0.05$ & $-0.02 \pm 0.05$ & 0.09 & $1.02(0.98$ to 1.05$)$ \\
1 CC & $22.83 \pm 0.03$ & $22.05 \pm 0.06$ & $0.78 \pm 0.07$ & $0.77 \pm 0.07$ & -0.23 & $0.59(0.56$ to 0.62$)$ \\
6U IP & $21.25 \pm 0.02$ & $22.59 \pm 0.09$ & $-1.34 \pm 0.09$ & $-0.58 \pm 0.09$ & 0.18 & $1.5(1.4$ to 1.59$)$ \\
6U NP & $21.96 \pm 0.03$ & $22.37 \pm 0.04$ & $-0.41 \pm 0.05$ & $-0.42 \pm 0.05$ & 0.12 & $1.32(1.29$ to 1.35$)$ \\
6A IP & $21.21 \pm 0.04$ & $22.19 \pm 0.02$ & $-0.98 \pm 0.04$ & $-0.99 \pm 0.04$ & 0.3 & $2(1.93$ to 1.92$)$ \\
6A NP & $22.45 \pm 0.06$ & $23.17 \pm 0.03$ & $-0.72 \pm 0.07$ & $-0.73 \pm 0.07$ & 0.22 & $1.66(1.58$ to 1.74$)$ \\
6CC IP & $23.66 \pm 0.03$ & $23.52 \pm 0.05$ & $0.14 \pm 0.06$ & $0.13 \pm 0.06$ & -0.04 & $0.92(0.88$ to 0.95$)$ \\
6CC NP & $23.75 \pm 0.05$ & $23.56 \pm 0.05$ & $0.19 \pm 0.07$ & $0.18 \pm 0.07$ & -0.05 & $0.89(0.84$ to 0.93$)$ \\
\hline
\end{tabular}

CT - threshold cycle, SEM - standard error of the mean, * - endogenous control, ** - calibrator sample. $\Delta \mathrm{CT}=\mathrm{CT}$ (Target) - CT (Endogenous control). $\Delta \Delta \mathrm{CT}=\Delta \mathrm{CT}$ (Target $-\Delta \mathrm{CT}$ (Calibrator). 
Table V. RQ analysis of FAK gene expression in the luminal surface uterine epithelial cells of day 1 and day 6 of pregnant rats. A fold change of 1.5 or more represents a significant difference in gene expression.

\begin{tabular}{|c|c|c|c|c|c|c|}
\hline Sample & FAK Ave $C_{T}$ & ${ }^{*}$ RFG Ave $\mathrm{C}_{\mathrm{T}}$ & $\Delta \mathrm{C}_{\mathrm{T}}$ & $\Delta \Delta \mathrm{C}_{\mathrm{T}}$ & $\begin{array}{l}\log _{10} \\
\left(2^{-\triangle \Delta C T}\right)\end{array}$ & $\begin{array}{l}\text { Fold change } \\
2 \Delta \Delta C T\end{array}$ \\
\hline$* * 1 \mathrm{U}$ & $25.64 \pm 0.02$ & $22.81 \pm 0.03$ & $2.83 \pm 0.04$ & $0 \pm 0.04$ & 0 & 1 (0.97 to 1.03$)$ \\
\hline $1 \mathrm{~A}$ & $25.55 \pm 0.06$ & $22.75 \pm 0.04$ & $2.8 \pm 0.07$ & $-0.03 \pm 0.07$ & 0.09 & 1.02 (0.97 to 1.07$)$ \\
\hline $1 \mathrm{CC}$ & $25.54 \pm 0.02$ & $22.05 \pm 0.06$ & $3.49 \pm 0.06$ & $0.66 \pm 0.06$ & -0.19 & $0.64(0.61$ to 0.66$)$ \\
\hline 6U IP & $24.11 \pm 0.07$ & $22.59 \pm 0.09$ & $1.52 \pm 0.11$ & $-1.31 \pm 0.11$ & 0.40 & 2.5 (2.3 to 2.68$)$ \\
\hline $6 \mathrm{UNP}$ & $25.19 \pm 0.02$ & $22.37 \pm 0.04$ & $2.82 \pm 0.04$ & $-0.01 \pm 0.04$ & 0.04 & 1.01 (0.98 to 1.04$)$ \\
\hline 6A IP & $23.50 \pm 0.17$ & $22.19 \pm 0.02$ & $1.31 \pm 0.17$ & $-1.52 \pm 0.17$ & 0.46 & 2.89 (2.55 to 3.23$)$ \\
\hline 6A NP & $24.84 \pm 0.02$ & $23.17 \pm 0.03$ & $1.67 \pm 0.08$ & $-1.16 \pm 0.08$ & 0.35 & 2.24 (2.11 to 2.36$)$ \\
\hline $6 \mathrm{CC}$ IP & $25.7 \pm 0.02$ & $23.52 \pm 0.05$ & $2.18 \pm 0.05$ & $-0.65 \pm 0.05$ & 0.20 & 1.57 (1.52 to 1.62$)$ \\
\hline 6CC NP & $26.07 \pm 0.06$ & $23.56 \pm 0.05$ & $2.51 \pm 0.08$ & $-0.32 \pm 0.08$ & 0.10 & $1.25(1.18$ to 1.32$)$ \\
\hline
\end{tabular}

CT - threshold cycle, SEM - standard error of the mean, * - endogenous control, ** - calibrator sample. $\Delta \mathrm{CT}=\mathrm{CT}$ (Target) - CT (Endogenous control). $\Delta \Delta \mathrm{CT}=\Delta \mathrm{CT}$ (Target $-\Delta \mathrm{CT}$ (Calibrator)

and FAK between untreated (control) and $\mathrm{CC}$ treated rats, anastrozole and $\mathrm{CC}$ treated rats at day $6(\mathrm{p} \leq 0.0001)$ suggesting the interpretation that $\mathrm{CC}$ appears to decrease their expression. Although there is no significant difference between untreated and anastrozole treated rats at day 6 $(\mathrm{p} \geq 0.05)$, the means for paxillin and FAK expression are higher in the anastrozole treated than in the untreated groups. Paxillin and FAK do not co-localize in focal adhesions at the base of the epithelium at day 1 , but they co-localize and increase their expression apically at day 6 suggesting their role in the implantation process.

With regard to the paxillin and FAK gene expression experiments in this study, at day 1 of pregnancy, paxillin gene expression is fairly similar (1.02-fold increase) in the anastrozole treated rats relative to the calibrator sample (day 1 untreated rats). This is also true for FAK gene expression (1.02-fold increase). Paxillin gene expression is slightly down-regulated (0.59-fold decrease) in the CC treated group when compared to the calibrator sample. This is also true for FAK gene expression (0.64-fold decrease). Notably, at day 6 of pregnancy, paxillin and FAK gene expression are significantly up-regulated (more than 1.5 -fold increase) $(\mathrm{p} \leq 0.0001)$ in the implantation and non-implantation sites in the anastrozole treated group relative to the calibrator. An increase in the paxillin gene expression is also noted in the day 6 implantation sites in the untreated group (more than 1.5-fold increase) while it has remained similar (1.32-fold increase) in the non-implantation sites relative to the calibrator sample. On the other hand, paxillin is downregulated with $\mathrm{CC}$ treatment at day 6 in implantation sites (0.92-fold decrease) and non-implantation sites (0.89-fold decrease) relative to the calibrator sample. Interestingly, CC seems not to down-regulate FAK gene expression in implantation and non-implantation sites at day 6 (1.57-fold increase and 1.25-fold increase respectively) when compared to the calibrator sample. In general, there is an increase in paxillin and FAK gene expression as pregnancy progresses, as reflected in the immunofluorescence experiments.

FAK is phosphorylated on tyrosine residues upon integrin-mediated adhesion to a substratum (Zhao \& Guan, 2009). FAK phosphorylation at tyrosine 397 (Y3a7) leads to recruitment of Src and Src-family kinases as well as to an increased phosphorylation of other focal adhesion proteins such as paxillin (Mitra et al., 2005). Other studies have demonstrated that site-specific FAK phosphorylation is also triggered by mechanical forces and determines physiological cellular responses to shear stress and cyclic stretch. In these studies, FAK has been noted to have multiple phosphorylation sites, making it an ideal anchor for participating in mechanotransduction (Cabodi et al., 2010). Similarly, some studies have found that FAK associates with multiple cell surface receptors and is at a point of convergence of integrin and growth factor mechanical signaling pathway (Long et al., 2010).

Moreover, FAK stabilizes the cytoskeleton by promoting focal adhesion turn-over through a rho-kinase (ROCK)-dependent pathway (Nehru et al., 2013). FAK is important in maintenance of normal cell survival and disruption of FAK signaling results in loss of substrate adhesion and apoptosis of anchorage-dependent cells such as endothelial cells (Lu \& Rounds, 2012). FAK maintains 
cell adhesion to integrins via PI3 kinase/AKt signaling ( $\mathrm{Lu}$ $\&$ Rounds). FAK is, therefore, a key component of focal adhesion complexes (Lu \& Rounds). On the contrary, other studies suggest that FAK does not regulate focal adhesion formation (Gilmore \& Burridge).

Of special note, progesterone enhances vascular endothelial cell migration via activation of FAK (Zheng $e t$ $a l ., 2012$ ). Additionally, progesterone has been seen to enhance breast cancer cell motility and invasion via extranuclear activation of FAK (Fu et al., 2010). This means that progesterone can regulate FAK activities. This is consistent with the findings of the present study in which the high FAK expression on the apical uterine epithelium together with paxillin, in the anastrozole and control groups coincides with the implantation period, which is also progesterone controlled. Taken together, these findings demonstrate that anastrozole appears to enhance the uterine receptivity during implantation.

While it is also interesting to note from the results of the present study that CC seems not to down-regulate FAK gene expression in implantation and non-implantation sites at day 6 (1.57-fold increase and 1.25-fold increase respectively) when compared to the calibrator sample, CC appears to down regulate FAK protein expression at day 6 of pregnancy. This discrepancy in the results raises the question of the normal molecular dogma of DNA-mRNAprotein. However, it could be argued that this is one of the limitations of real-time qPCR in that detection of the presence of an mRNA provides no information on whether that mRNA will be translated into a protein or indeed whether a functional protein is translated at all (Derveaux et al., 2010). This means that some of the FAK mRNAs might have not been translated into functional proteins in the day $6 \mathrm{CC}$ treated animals, and thus their increased gene and decreased protein expression. Moreover, earlier studies have suggested similar reasons (Derveaux et al.). It follows, therefore, that not all mRNAs are translated into proteins, and thus the decreased FAK protein expression in the $\mathrm{CC}$ treated rats at day 6 in the immunofluorescence experiments in this study, which might affect the attachment of blastocysts onto the uterus during implantation. Moreover, $\mathrm{CC}$ reduces endometrial thickness (Lacin et al., 2001), blood flow, morphological abnormalities in the rat uteri, embryo development and pregnancy rates (Bao et al., 2009) suggesting that CC may disrupt blastocyst implantation, and thus associated with low pregnancy rates (Nutu et al.; Reefhuis et al., 2011).

If this study had found that CC significantly increased FAK protein expression, the question of whether this specific biological change interferes with implantation and pregnancy rates would still be a matter of debate.
Moreover, FAK and vinculin have been shown to strengthen cellular stiffness in mouse embryonic fibroblasts (Klemm et al., 2009). FAK is also known to be crucial in the coordination of the appropriate mechanical properties to cell-cell contacts through cadherin-catenin-actin interactions in which focal adhesions sense the physical properties of the extracellular matrix (ECM) and organize the cytoskeleton accordingly (Quadri, 2012). Other studies have suggested that FAK is a mediator of crosstalk between integrin-mediated FAs and intercellular adherens junctions (Zachary, 2003). This clearly shows that FAK is at the centre of focal adhesion assembly and activation (Kaneko et al., 2012) and therefore, anastrozole might positively affect its expression and activities during implantation.

Immunofluorescence and focal adhesion localization studies done in rats during early pregnancy have revealed that FAK does not localize at the site of focal adhesions, instead it is localized to the site of cell-to-cell contact and colocalize with ZO-1 at day 1 of pregnancy (Kaneko et al., 2012). At day 6 of pregnancy, FAK expression increases at the apical region of the rat uterine luminal epithelial cells, regulated by progesterone (Kaneko et al., 2012). It is not surprising, therefore, to see in the current study that FAK re-locates and increases its expression apically in the rat uterine epithelial cells at day 6 in both untreated and anastrozole treated rats. Moreover, Junctional barrier complexes undergo major alterations during the plasma membrane transformation of uterine epithelial cells in early pregnancy (Murphy, 2000). The implication of these morphological and molecular alterations is to have reduced paracellular permeability by the time of blastocyst attachment while the epithelial cells are less firmly attached to each other, and to their extracellular environment (Murphy). Taken together, there is assembly and disassembly of the cytoskeleton in uterine epithelial cells during implantation.

Tyrosine phosphorylation is also an important element in paxillin dynamics at FAs (Hu et al., 2006). FAK is targeted to the FA complexes via direct binding to paxillin (Liu et al., 2002) and p130Cas (Polte \& Hanks, 1997). Multiple interactions between FAK, Src, p130Cas, and paxillin regulate the dynamic FA assembly and disassembly, as reviewed by Playford \& Schaller (2004). Disruption of these interactions causes cell detachment (Playford \& Schaller; Zouq et al., 2009).

Furthermore, earlier hormonal studies done on rats have demonstrated that paxillin expression is along the basal cell surface of the uterine epithelial cells with estrogen treatment (Kaneko et al., 2009). On the other hand, there is a reduction or no staining of paxillin at the basal surface of uterine epithelial cells with progesterone treatment, which is 
also observed at the time of implantation (Kaneko et al., 2009). This is in agreement with the observation in the current study in which paxillin is seen to disassemble from the basal surface of the uterine epithelial cells then relocates and increases its expression apically at day 6 of pregnancy in untreated and anastrozole treated rats. The implication of this could be for the blastocyst to easily invade the endometrium.

In conclusion, the immunofluorescence and gene expression findings of the focal adhesions proteins, paxillin and FAK, which are uterine receptivity markers, appear to demonstrate that anastrozole is implantation friendly. Anastrozole may be a suitable alternative drug used for hyperovulation or just to promote fertility in patients, particularly those suffering from polycystic ovary syndrome or are unresponsive to chlomiphene citrate (CC).

\section{ACKNOWLEDGMENTS}

We thank the staff of the central animal unit, microscopy and microanalysis units of the University of the Witwatersrand, staff and management of Newcastle University, NuMed campus Malaysia for their support. This work was funded by a grant from the National Research Foundation and Medical Research Council of South Africa (to $\mathrm{MH}$ ); Government of Norway (NORAD project) and College of Medicine of the University of Malawi.

MWAKIKUNGA, A.; ADEFOLAJU, G. A.; SCHEPARTZ, L. \& HOSIE, M. J. El anastrozol promueve la implantación alterando la expresión de paxilina y FAK en el epitelio uterino luminal de rata. Int. J. Morphol., 38(1):165-175, 2020.

RESUMEN: Para reemplazar el citrato de clomifeno (CC) es necesario un inductor de hiperovulación alternativo, ya que no es adecuado para mujeres con síndrome de ovario poliquístico y está asociado con tasas bajas de embarazo. El anastrozol es un inductor eficaz del hiper-ovulador, pero no se ha investigado adecuadamente. Con el fin de determinar la efectividad del anastrozol como inductor del hiper-ovulador y, en cierta medida, compararlo con CC en situaciones similares, este estudio determinó los efectos de estos fármacos en la expresión de las proteínas de adhesión focal, paxillin y FAK, uterinas marcadores de receptividad en la superficie luminal de células uterinas epiteliales, del día 1 y día 6 en ratas Wistar preñadas. Los resultados muestran que la paxilina se localiza en adherencias focales en la base de las células epiteliales uterinas en el día 1 del embarazo, mientras que en el día 6, la paxilina se desmonta de las adherencias focales basales y localiza y aumenta su expresión apicalmente. FAK se expresa débilmente en el aspecto basal de las células epiteliales uterinas, mientras que se expresa moderadamente en el contacto de célula a célula en el día 1 en todos los grupos, donde se separa y se reubica apicalmente y se expresa con mayor intensidad el día 6 de la preñez, en pacientes no tratados y tratados. ratas tratadas con anastrozol. Aunque la paxillina se localiza apicalmente en el día 6, su expresión está significativamente disminuida con el tratamiento con CC, lo que sugiere su interferencia con el proceso de implantación. Estos hallazgos sugieren que el anastrozol podría favorecer el proceso de implantación.

PALABRAS CLAVE: Implantación, útero; Gravidez temprana; Paxilina; FAK; Proteínas de adhesión focal.

\section{REFERENCES}

Al-Bader, M. D. \& Al-Sarraf, H. A. Housekeeping gene expression during fetal brain development in the rat-validation by semi-quantitative RT-PCR. Brain Res. Dev. Brain Res., 156(1):38-45, 2005.

Al-Omari, W. R.; Sulaiman, W. R. \& Al-Hadithi, N. Comparison of two aromatase inhibitors in women with clomiphene-resistant polycystic ovary syndrome. Int. J. Gynaecol. Obstet., 85(3):289-91, 2004.

Badawy, A.; Mosbah, A. \& Shady, M. Anastrozole or letrozole for ovulation induction in clomiphene-resistant women with polycystic ovarian syndrome: a prospective randomized trial. Fertil. Steril., 89(5):1209-12, 2008.

Bao, S. H.; Sheng, S. L.; Peng, Y. F. \& Lin, Q. D. Effects of letrozole and clomiphene citrate on the expression of HOXA10 and integrin alpha v beta 3 in uterine epithelium of rats. Fertil. Steril., 91(1):244-8, 2009.

Cabodi, S.; Di Stefano, P.; Leal, M. del P.; Tinnirello, A.; Bisaro, B.; Morello, V.; Damiano, L.; Aramu, S.; Repetto, D.; Tornillo, G.; et al. Integrins and signal transduction. Adv. Exp. Med. Biol., 674:43-54, 2010.

Casper, R. F. \& Mitwally, M. F. Use of the aromatase inhibitor letrozole for ovulation induction in women with polycystic ovarian syndrome. Clin. Obstet. Gynecol., 54(4):685-95, 2011.

Derveaux, S.; Vandesompele, J. \& Hellemans, J. How to do successful gene expression analysis using real-time PCR. Methods, 50(4):227-30, 2010.

Dukes, M.; Edwards, P. N.; Large, M.; Smith, I. K. \& Boyle, T. The preclinical pharmacology of "Arimidex" (anastrozole; ZD1033)--a potent, selective aromatase inhibitor. J. Steroid Biochem. Mol. Biol., 58(4):439-45, 1996.

Englund, P.; Lindroos, E.; Nennesmo, I.; Klareskog, L. \& Lundberg, I. E. Skeletal muscle fibers express major histocompatibility complex class II antigens independently of inflammatory infiltrates in inflammatory myopathies. Am. J. Pathol., 159(4):1263-73, 2001.

Fabry, B.; Klemm, A. H.; Kienle, S.; Schäffer, T. E. \& Goldmann, W. H. Focal adhesion kinase stabilizes the cytoskeleton. Biophys. J., 101(9):2131-8, 2011.

Faoláin, E. O.; Hunter, M. B.; Byrne, J. M.; Kelehan, P.; Lambkin, H. A.; Byrne, H. J. \& Lyng, F. M. Raman spectroscopic evaluation of efficacy of current paraffin wax section dewaxing agents. J. Histochem. Cytochem., 53(1):121$9,2005$.

Fu, X. D.; Goglia, L.; Sanchez, A. M.; Flamini, M.; Giretti, M. S.; Tosi, V.; Genazzani, A. R. \& Simoncini, T. Progesterone receptor enhances breast cancer cell motility and invasion via extranuclear activation of focal adhesion kinase. Endocr. Relat. Cancer, 17(2):431-43, 2010.

Gilmore, A. P. \& Burridge, K. Regulation of vinculin binding to talin and actin by phosphatidyl-inositol-4-5-bisphosphate. Nature, 381(6582):531-5, 1996.

Hirata, H.; Sokabe, M. \& Lim, C. T. Molecular mechanisms underlying the force-dependent regulation of actin-to-ECM linkage at the focal adhesions. Prog. Mol. Biol. Transl. Sci., 126:135-54, 2014.

Hong, E. J.; Park, S. H.; Choi, K. C.; Leung, P. C. \& Jeung, E. B. Identification of estrogen-regulated genes by microarray analysis of the uterus of immature rats exposed to endocrine disrupting chemicals. Reprod. Biol. Endocrinol., 4:49, 2006.

Hosie, M.; Adamson, M. \& Penny, C. Actin binding protein expression is altered in uterine luminal epithelium by clomiphene citrate, a synthetic estrogen receptor modulator. Theriogenology, 69(6):700-13, 2008.

Hosie, M.; Terry, V. \& Murphy, C. Expression of glucosamine trisaccharides on the rat uterine surface is altered by clomiphene citrate. III. Relationship with implantation regimes and pregnancy. Acta Histochem., 105(4):32938, 2003. 
Hu, Y. L.; Haga, J. H.; Miao, H.; Wang, Y.; Li, Y. S. \& Chien, S. Roles of microfilaments and microtubules in paxillin dynamics. Biochem. Biophys. Res. Commun., 348(4):1463-71, 2006.

Jaramillo, L. M.; Balcazar, I. B.; \& Duran, C. Using vaginal wall impedance to determine estrous cycle phase in Lewis rats. Lab. Anim. (N. Y.), 41(5):122-8, 2012.

Kaneko, Y.; Lecce, L. \& Murphy, C. R. Ovarian hormones regulate expression of the focal adhesion proteins, talin and paxillin, in rat uterine luminal but not glandular epithelial cells. Histochem. Cell Biol., 132(6):613-22, 2009.

Kaneko, Y.; Lecce, L.; Day, M. L. \& Murphy, C. R. Focal adhesion kinase localizes to sites of cell-to-cell contact in vivo and increases apically in rat uterine luminal epithelium and the blastocyst at the time of implantation. J. Morphol., 273(6):639-50, 2012.

Kaneko, Y.; Lecce, L.; Day, M. L. \& Murphy, C. R. b(1) and b(3) integrins disassemble from basal focal adhesions and $\mathrm{b}(3)$ integrin is later localised to the apical plasma membrane of rat uterine luminal epithelial cells at the time of implantation. Reprod. Fertil. Dev., 23(3):481-95, 2011.

Kaneko, Y.; Lindsay, L. A. \& Murphy, C. R. Focal adhesions disassemble during early pregnancy in rat uterine epithelial cells. Reprod. Fertil. Dev., 20(8):892$9,2008$.

Karaer, O.; Vatansever, H. S.; Oruç, S.; Ozbilgin, K.; Cilaker, S. \& Koyuncu, M. F. The aromatase inhibitor anastrozole is associated with favorable embryo development and implantation markers in mice ovarian stimulation cycles. Fertil. Steril., 83(6):1797-806, 2005.

Kilic-Okman, T.; Kucuk, M. \& Altaner, S. Comparison of the effects of letrozole and clomiphene citrate on ovarian follicles, endometrium, and hormone levels in the rat. Fertil. Steril., 80(6):1330-2, 2003.

Klemm, A. H.; Diez, G.; Alonso, J. L. \& Goldmann, W. H. Comparing the mechanical influence of vinculin, focal adhesion kinase and p53 in mouse embryonic fibroblasts. Biochem. Biophys. Res. Commun., 379(3):799-801, 2009.

Lacin, S.; Vatansever, S.; Kuscu, N. K.; Koyuncu, F.; Ozbilgin, K. \& Ceylan, E. Clomiphene citrate does not affect the secretion of alpha3, alphaV and beta1 integrin molecules during the implantation window in patients with unexplained infertility. Hum. Reprod., 16(11):2305-9, 2001.

Lele, T. P.; Thodeti, C. K.; Pendse, J. \& Ingber, D. E. Investigating complexity of protein-protein interactions in focal adhesions. Biochem. Biophys. Res. Commun., 369(3):929-34, 2008.

Li, Y. Q.; Bai, B.; Zheng, Q. Q.; Yan, H. \& Zhuang, G. H. Quantitative study of iron metabolism-related genes expression in rat. Biomed. Environ. Sci., 26(10):808-19, 2013

Liu, G.; Guibao, C. D. \& Zheng, J. Structural insight into the mechanisms of targeting and signaling of focal adhesion kinase. Mol. Cell. Biol., 22(8):275160, 2002.

Lo, J.; Di Nardo, G.; Griswold, J.; Egbuta, C.; Jiang, W.; Gilardi, G. \& Ghosh, D. Structural basis for the functional roles of critical residues in human cytochrome p450 aromatase. Biochemistry, 52(34):5821-9, 2013.

Long, W.; Yi, P.; Amazit, L.; LaMarca, H. L.; Ashcroft, F.; Kumar, R.; Mancini, M. A.; Tsai, S. Y.; Tsai, M. J. \& O'Malley, B. W. SRC-3Delta4 mediates the interaction of EGFR with FAK to promote cell migration. Mol. Cell, 37(3):321-32, 2010.

$\mathrm{Lu}$, Q. \& Rounds, S. Focal adhesion kinase and endothelial cell apoptosis. Microvasc. Res., 83(1):56-63, 2012.

Mitra, S. K.; Hanson, D. A. \& Schlaepfer, D. D. Focal adhesion kinase: in command and control of cell motility. Nat. Rev. Mol. Cell Biol., 6(1):56-68, 2005.

Mitwally, M. F. \& Casper, R. F. Aromatase inhibition for ovarian stimulation: future avenues for infertility management. Curr. Opin. Obstet. Gynecol., 14(3):255-63, 2002 .

Mitwally, M. F. \& Casper, R. F. Use of an aromatase inhibitor for induction of ovulation in patients with an inadequate response to clomiphene citrate. Fertil. Steril., 75(2):305-9, 2001.

Mohan, K. H.; Pai, S.; Rao, R.; Sripathi, H. \& Prabhu, S. Techniques of immunofluorescence and their significance. Indian J. Dermatol. Venereol. Leprol., 74(4):415-9, 2008

Murphy, C. R. Understanding the apical surface markers of uterine receptivity: pinopods-or uterodomes? Hum. Reprod., 15(12):2451-4, 2000.

Mwakikunga, A. \& Hosie, M. J. Anastrozole is a dose-specific superovulator and favors implantation in rats: a prospective study. Cell Tissue Res., 364(1):209$17,2016$.
Mwakikunga, A. R.; Clubine, A. L. \& Wiens, D. J. Homocysteine and cardiac neural crest cell cytoskeletal proteins in the chick embryo. Int. J. Biol., 3(2):43-56, 2011.

Nehru, V.; Almeida, F. N. \& Aspenström, P. Interaction of RhoD and ZIP kinase modulates actin filament assembly and focal adhesion dynamics. Biochem. Biophys. Res. Commun., 433(2):163-9, 2013.

Nutu, M.; Feng, Y.; Egecioglu, E.; Weijdegård, B.; Stener-Victorin, E. \& Shao, R. Stromal cell-specific apoptotic and antiestrogenic mechanisms may explain uterine defects in humans after clomiphene citrate therapy. Am. $J$. Obstet. Gynecol., 203(1):65.e1-65.e10, 2010.

Pakrasi, P. L. \& Tiwari, A. Evidence of increased endometrial vascular permeability at the time of implantation in the short-nosed fruit bat, Cyanopterus sphinx. Anim. Reprod. Sci., 101(1-2):179-85, 2007.

Playford, M. P. \& Schaller, M. D. The interplay between Src and integrins in normal and tumor biology. Oncogene, 23(48):7928-46, 2004.

Polte, T. R. \& Hanks, S. K. Complexes of focal adhesion kinase (FAK) and Crk-associated substrate (p130(Cas)) are elevated in cytoskeletonassociated fractions following adhesion and Src transformation. Requirements for Src kinase activity and FAK proline-rich motifs. J. Biol. Chem., 272(9):5501-9, 1997.

Psychoyos, A.; Nikas, G. \& Gravanis, A. The role of prostaglandins in blastocyst implantation. Hum. Reprod., 10 Suppl. 2:30-42, 1995.

Quadri, S. K. Cross talk between focal adhesion kinase and cadherins: role in regulating endothelial barrier function. Microvasc. Res., 83(1):3-11, 2012.

Racette, L.; Casson, P. R.; Claman, P.; Zackon, D. H. \& Casson, E. J. An investigation of the visual disturbances experienced by patients on clomiphene citrate. Fertil. Steril., 93(4):1169-72, 2010.

Reefhuis, J.; Honein, M. A.; Schieve, L. A.; Rasmussen, S. A. \& National Birth Defects Prevention Study. Use of clomiphene citrate and birth defects, National Birth Defects Prevention Study, 1997-2005. Hum. Reprod., 26(2):451-7, 2011.

Salgia, R. Role of c-Met in cancer: emphasis on lung cancer. Semin. Oncol., 36(2 Suppl. 1):S52-8, 2009.

Schmittgen, T. D. \& Livak, K. J. Analyzing real-time PCR data by the comparative C(T) method. Nat. Protoc., 3(6):1101-8, 2008.

Singletary, S. J.; Kirsch, A. J.; Watson, J.; Karim, B. O.; Huso, D. L.; Hurn, P. D. \& Murphy, S. J. Lack of correlation of vaginal impedance measurements with hormone levels in the rat. Contemp. Top. Lab. Anim. Sci., 44(6):3742, 2005.

Tredway, D. R. \& Schertz, J. C. Anastrozole versus clomiphene citrate: which is better for ovulation induction? Fertil. Steril., 95(5):1549-51, 2011.

Zachary, I. VEGF signalling: integration and multi-tasking in endothelial cell biology. Biochem. Soc. Trans., 31(Pt. 6):1171-7, 2003.

Zhao, J. \& Guan, J. L. Signal transduction by focal adhesion kinase in cancer Cancer Metastasis Rev., 28(1-2):35-49, 2009.

Zheng, S.; Huang, J.; Zhou, K.; Xiang, Q.; Zhang, Y.; Tan, Z.; Simoncini, T.; Fu, X. \& Wang, T. Progesterone enhances vascular endothelial cell migration via activation of focal adhesion kinase. J. Cell. Mol. Med., 16(2):296-305, 2012.

Zouq, N. K.; Keeble, J. A.; Lindsay, J.; Valentijn, A. J.; Zhang, L.; Mills, D.; Turner, C. E.; Streuli, C. H. \& Gilmore, A. P. FAK engages multiple pathways to maintain survival of fibroblasts and epithelia: differential roles for paxillin and p130Cas. J. Cell Sci., 122(3):357-67, 2009.

\section{Corresponding author: \\ Gbenga A Adefolaju}

Department of Pre-Clinical Sciences

School of Health Care Sciences

University of Limpopo

Private Bag $\times 1106$

Sovenga 0727

SOUTH AFRICA

Received: $15-12-2018$

Accepted: 26-07-2019

Email: gbenga.adefolaju@ul.ac.za anton.ul2016@gmail.com 